\title{
Trends in prevalence of hepatitis B virus infection among Albanian blood donors, 1999-2009
}

Vjollca Durro ${ }^{1 *}$, Shpetim Qyra ${ }^{2}$

\begin{abstract}
Background: Hepatitis B virus (HBV) was among the first virus known to be transmitted by blood and blood productions. The objective of this study is to determine the trend of hepatitis B virus in blood donors.

Materials and methods: In this study 79274 blood donors were retrospectively evaluated for HBsAg. The donors were selected using personal questionnaire, physical examination and testing blood before donation. Blood banks records are used as source of information. The blood donors samples were analyzed for the presence of hepatitis $B$ surface antigen (HBsAg) by commercial available kits ELISA method, third generation (from Abbott laboratory, Germany). A sample was considered as HBsAg positive when found twice repeatedly reactive. Reactive samples were not confirmed with addition tests.

Results: In the evaluation data, we found out that from 79274 of the total healthy blood donors, 15983 were voluntary donors, 52876 were family replacement donors and 10424 commercial blood donors. The prevalence of HBsAg in blood donors was 7.9\%. It was increased steadily from 5.9\% in 1999 to $9.1 \%$ in 2006 and decreased in $7.9 \%$ in 2009. According to blood donors status the HBsAg prevalence was $10.5 \%$ in commercial blood donors, $8.1 \%$ in voluntary donors and $8.6 \%$ in family replacement donors. The prevalence of anti-HBC in blood donors was $59.1 \%$.

Conclusion: The prevalence of HBsAg was lower in voluntary non remunerate blood donors than commercial donors and family replacement blood donors. In FDs the prevalence was higher than VDs but lower than CDs. So, it is important to encourage the voluntary blood donors to become regularly blood donors.
\end{abstract}

\section{Background}

Hepatitis B virus (HBV) was among the first virus known to be transmitted by blood and blood products. HBV infection from transfusions became rare after the introduction of the HBsAg test in early 1970, but remains one of the most common serious complications of transfusion particularly in countries with high and intermediate prevalence of HBV [1-4]. The residual transmission risk of HBV through transfusion is higher [5-8]. This is attributed to the interval between initial HBV infection and the detection of hepatitis B surface antigen (HBsAg), resulting in a long window phase during which the virus is transmissible $[9,10]$. After the implementation of HBsAg screening in the 1975s, there have been no further measures in Albania to decrease

\footnotetext{
*Correspondence: dvjollca@yahoo.com

'Hospital Planning Directory, Ministry of Health, Bulevardi "Bajram Curri",

No.1, Tirana, Albania

Full list of author information is available at the end of the article
}

the residual risk of $\mathrm{HBV}$ transmission, other than improving the sensitivity of the HBsAg assay. Development of sensitive assays to detect HBV-DNA showed that healthy HBsAg-negative donors who are anti-HBc positive, may harbour an occult $\mathrm{HBV}$ infection and maintain HBV-DNA sequences in their liver and blood, thus representing potential sources of HBV transmission $[11,12]$. Evaluation of data on the prevalence of HBV, among blood donors permits an assessment of the occurrence of infection in the blood donor population and consequently the safety of the collected donations. This study was performed to assess prevalence and trends of the viral hepatitis B during last decade (20002009 years), among blood donors in Tirana. Moreover, in a pilot study, we also explored the prevalence of anti$\mathrm{HBC}$ among randomly selected HBsAg negative blood donor samples.

\section{Ciomed Central}




\section{Materials and methods}

In this study 79274 blood donors were retrospectively evaluated for HBsAg. The donors were selected using personal questionnaire, physical examination and testing blood before donation (as $\mathrm{Hb}$ level, blood pressure, body weight, temperature). Blood banks records are used (personal donor sheet, donation's records) as source of information. A first time blood donors is a donors who has donated blood for first time and only once. A regular blood donors is donors who has donated blood more than two time during one year.

In this study family replacement donors and voluntary non remunerate blood donors are first time blood donors. We haven't regular blood donors from these groups. Family replacement donors are donors who have donated the same number of units of blood as of patient's requirements, despite the blood group. A friend or family member of the recipient donates blood to replace the stored blood used in a transfusion, ensuring a consistent supply.

To define the prevalence of HBV infection the number of positive donors for each years is divided by the total number of donors for each years.

\section{Laboratory testing \\ Tests for $\mathrm{HBsAg}$}

The blood donors samples were analyzed for the presence of hepatitis B surface antigen (HBsAg) by commercial available kits (as was presented in table 1). A sample was considered as HBsAg positive when found twice repeatedly reactive. Reactive samples were not confirmed with addition tests. All reactive donors were rejected from further blood donations.

\section{Tests for anti-HBC}

The blood donor samples were analyzed for the presence of anti-HBc using third generation monoelisa kit anti HBC plus (Bio - Rad) with sensitivity $0.5 \mathrm{U} \mathrm{PEI} / \mathrm{ml}$ for IgG dhe $8 \mathrm{U} \mathrm{PEI} / \mathrm{ml}$ for IgM and specificity $99.91 \%$

\section{Results}

A total of 79274 blood donors have donated blood during 10 years. In the evaluation data, we found out that from the total 79274 healthy blood donors, 15983 were voluntary donors, 52876 were replacement donors and 10424 commercial blood donors. Table 2 shows the number of blood donors who have donated blood during 1999-2009 years. The number of blood donors was progressively increased during the years from 5233 in 1999 to 14352 in 2009. The number of commercial blood donors was decreased from 1714 in 1999 to 284 in 2009. The number of voluntary non remunerate blood donors was increased from 1200 in 1999 to 3639 in 2009 donors and family replacement blood donors from 2319 in 1999 to 10429 in 2009.

Table 3 shows the prevalence of HBsAg in blood donors between 1999-2009 years. The HBsAg was detected in 5933 blood donors out of 79274 blood donors screened. The prevalence of HBsAg in blood donors was $7.9 \%$. It was increased steadily from $5.9 \%$ in 1999 to $9.1 \%$ in 2006 and decreased in $7.9 \%$ in 2009.

Table 4 shows the prevalence of HBsAg based on donor's status. HBsAg was detected in 60 first time commercial blood donors out of 561 firs time commercial blood donors tested (prevalence 10.5\%); in 1298 first time voluntary non remunerate blood donors out of 15983 first time voluntary non remunerate blood donors voluntary tested (prevalence $8.1 \%$ ); in 4543 family replacement blood donors out of 52876 family replacement blood donors tested (prevalence 8.6\%).

Table 5 shows the prevalence of anti-HBc in blood donors. Anti-HBc was detected in 133 blood donors out of 225 blood donors tested (prevalence 59.1\%).

Table 1 The HBsAg screening kits used 1999-2009

\begin{tabular}{|c|c|c|c|c|}
\hline Years & Screening kit & Manufacture & Sensitivity & Method \\
\hline 1999 & Auszyme Monoclonal HBsAg & Quantum ॥ ABBOT & Ad $04 \mathrm{ng} / \mathrm{ml}$, ay $0.7 \mathrm{ng} / \mathrm{ml}$ & Manual \\
\hline 2000 & Auszyme Monoclonal HBsAg & Quantum II ABBOT & Ad $04 \mathrm{ng} / \mathrm{ml}$, ay $0.7 \mathrm{ng} / \mathrm{ml}$ & Manual \\
\hline 2001 & Auszyme Monoclonal HBsAg & Quantum ॥ ABBOT & Ad $04 \mathrm{ng} / \mathrm{ml}$, ay $0.7 \mathrm{ng} / \mathrm{ml}$ & Manual \\
\hline 2002 & Auszyme Monoclonal HBsAg & Quantum ॥ ABBOT & Ad $04 \mathrm{ng} / \mathrm{ml}$, ay $0.7 \mathrm{ng} / \mathrm{ml}$ & Manual \\
\hline 2003 & IMx & ABBOT & Ad $0.22 \mathrm{ng} / \mathrm{ml}$ Ay $0.17 \mathrm{ng} / \mathrm{ml}$ & Semi automatic \\
\hline 2004 & IMx & ABBOT & Ad $0.22 \mathrm{ng} / \mathrm{ml}$ Ay $0.17 \mathrm{ng} / \mathrm{ml}$ & Semi automatic \\
\hline 2005 & IMx & ABBOT & Ad $0.22 \mathrm{ng} / \mathrm{ml}$ Ay $0.17 \mathrm{ng} / \mathrm{ml}$ & Semi automatic \\
\hline 2006 & AxSYM HBsAg (MEIA) & ABBOT & $\begin{array}{l}\text { Ad } 0.15 \mathrm{ng} / \mathrm{mL} \\
\text { Ay } 0.12 \mathrm{ng} / \mathrm{mL} \\
\leq 0.5 \mathrm{ng} / \mathrm{mL}\end{array}$ & automated \\
\hline 2007 & AXSYM CMIA & ABBOT & $100 \%$ & automated \\
\hline 2008 & Architect & ABBOT & $100 \%$ & fully automate \\
\hline 2009 & Architect & ABBOT & $100 \%$ & fully automate \\
\hline
\end{tabular}


Table 2 Blood donors during 1999-2009

\begin{tabular}{lcccccccccccc}
\hline Blood donors & \multicolumn{10}{c}{ Years } \\
\hline & $\mathbf{1 9 9 9}$ & $\mathbf{2 0 0 0}$ & $\mathbf{2 0 0 1}$ & $\mathbf{2 0 0 2}$ & $\mathbf{2 0 0 3}$ & $\mathbf{2 0 0 4}$ & $\mathbf{2 0 0 5}$ & $\mathbf{2 0 0 6}$ & $\mathbf{2 0 0 7}$ & $\mathbf{2 0 0 8}$ & $\mathbf{2 0 0 9}$ & Total number \\
\hline Voluntary donors No. & 1200 & 1110 & 210 & 509 & 506 & 605 & 1369 & 2027 & 2330 & 2478 & 3639 & 15983 \\
$\%$ & 22.9 & 25.9 & 6 & 12.9 & 11.6 & 11.7 & 19.1 & 23.9 & 20.8 & 21.3 & 25.3 & \\
\hline Family replacement donors No. & 2319 & 1810 & 1965 & 2224 & 2774 & 3464 & 4877 & 5840 & 8403 & 8771 & 10429 & 52876 \\
$\%$ & 44.3 & 42.2 & 56 & 56.7 & 63.5 & 67.1 & 68.4 & 69.2 & 74.9 & 75.4 & 72.6 & \\
\hline Commercial donors No. & 1714 & 1365 & 1333 & 1199 & 1088 & 1091 & 891 & 584 & 493 & 382 & 284 & 10424 \\
\% & 32.8 & 31.9 & 38 & 30.6 & 24.9 & 21.2 & 12.5 & 6.9 & 4.3 & 3.3 & 1.9 & \\
\hline Total & 5233 & 4285 & 3508 & 3923 & 4368 & 5160 & 7137 & 8451 & 11226 & 11631 & 14352 & 79274 \\
\hline
\end{tabular}

According to blood donors groups anti-HBc was detected in 73 first time blood donors out of 103 blood donors tested (prevalence $70.8 \%$ ); in 60 regular blood donors out of 122 blood donors tested (prevalence $49.1 \%)$.

\section{Discussed}

Viral Hepatitis, especially hepatitis B in Albania continues to be a public health problem because of Albania is the highly endemic area for hepatitis B. In Albania the prevalence of $\mathrm{HBsAg}$ is $19 \%$ and anti-HBc $62 \%$ [13]. The endemicity of hepatitis $B$ is described by the prevalence of HBsAg in the general population of a defined geographical area, and it varies considerably globally: HBsAg prevalence's of $>8 \%$ are typical of highly endemic areas [14-17]. One of the primary concerns of Health Department is the need to suppress the spread of this highly contagious. The national blood transfusion service in Albania is only responsible body for collection, processing, testing and distribution of blood and blood products under supervision of Ministry of Health. HBsAg screening of all blood donations was mandatory

Table 3 HBsAg distribution in blood donors during 19992009

\begin{tabular}{llcc}
\hline \multirow{2}{*}{ Years } & Total number of blood donors tested & \multicolumn{2}{c}{$\begin{array}{c}\text { Positive blood } \\
\text { donors }\end{array}$} \\
\cline { 3 - 4 } & & No & $\%$ \\
\hline 1999 & 5233 & 307 & 5.9 \\
\hline 2000 & 4285 & 235 & 6.5 \\
\hline 2001 & 3508 & 178 & 5.1 \\
\hline 2002 & 3923 & 272 & 6.9 \\
\hline 2003 & 4368 & 275 & 6.3 \\
\hline 2004 & 5160 & 376 & 7.3 \\
\hline 2005 & 7137 & 568 & 7.95 \\
\hline 2006 & 8451 & 769 & 9.1 \\
\hline 2007 & 11226 & 898 & 8 \\
\hline 2008 & 11631 & 920 & 7.9 \\
\hline 2009 & 14352 & 1135 & 7.9 \\
\hline Total & 79274 & 5933 & 7.5 \\
\hline
\end{tabular}

in national level, since 1975. In present study we analyzed the profile of blood donors and estimated the prevalence of HBsAg. Traditionally paid donors (commercial donors) were the main source of blood in Albania. The first efforts for the voluntary blood donation began in 1994 with a cooperation between National Blood Service and Red Cross. One of the most important problems of blood transfusion service in Albania has always been reliance on professional blood donors (paid blood donors) that still exist even if has been reduce significantly. According to the data used in this study, in 1999 commercial blood donors composed $32.8 \%$ of blood donors versus $1.9 \%$ in 2009. During last years blood donors profile has changed as result implementation of national strategy for blood safety, launched in 2005. Exclusion of paid donors was achieved by rejecting the paid donor for the first time. First time commercial blood donors were prohibited since 2008 . This change resulted in a very high percentage of first time blood donors from voluntary blood donors and family replacement blood donors groups. During these years family replacement blood donors constitute the largest group of blood donors in Albania. Our data in this study showed that $72.6 \%$ of blood donors were family replacement blood donors(in 2009).

The first lines of defence protection to assure the safety of blood for transfusion are rejected from donation the candidate of blood donors who are undergoing acute infection. Careful history taking is very important because the vast majority of infectious virus transmitted by transfusion are those causing in apparent or sub clinical infections in blood donors $[18,19]$. The prevalence of HBsAg in blood donors population depends on some

Table 4 Distribution of HBsAg based on donor status

\begin{tabular}{llll}
\hline Donor status & Screened & \multicolumn{2}{l}{ HBsAg } \\
\cline { 3 - 4 } & No & No & $\%$ \\
\hline First time commercial donors & 561 & 60 & 10.5 \\
\hline First time Voluntary blood donors & 15983 & 1298 & 8.1 \\
\hline Family replacement blood donors & 52876 & 4543 & 8,6 \\
\hline
\end{tabular}


Table 5 Anti-HBc prevalence in blood donors

\begin{tabular}{llll}
\hline Donor status & Screened & Anti-HBc \\
\cline { 2 - 4 } & No & No & $\%$ \\
\hline Regular blood donors & 122 & 60 & 49.1 \\
\hline First time blood donors & 103 & 73 & 70.8 \\
\hline Total & 225 & 133 & 59.1 \\
\hline
\end{tabular}

factor as the prevalence of this virus in general population, diagnose of hepatitis $\mathrm{B}$ infection and sensitivity of screening test.

Our data (table 3/figure 1) showed the higher prevalence of HBsAg in blood donors, 7.9\% (it ranging from $5.9 \%$ in 1999 to $7.9 \%$ in 2009 ) comparing with neighbor countries. So, the prevalence of HBsAg in blood donors population is $4,1 \%$ in Turkey, $0.4 \%$ in Greece, $4.2 \%$ in Kosovo, $1.32 \%$ in Macedonia, $0.4 \%$ in Italy [20-25].

The higher prevalence of HBsAg in blood donors reflects epidemiological situation of HBV in our country. According to previous studies in different group of Albanian population the prevalence of $\mathrm{HBsAg}$ were respectively in military recruitment $13,2 \%$, in students 8 $15.3 \%$ and pediatric aged $1.4-3.9 \%$ [26]. These data show that in blood donors the HBsAg prevalence is lower than general population because of pre-donation selection of blood donors who are interviewed with screening questionnaire.

As it is shown in the figure 1 there is an increase in prevalence of HBsAg in our donor population during years. This could be the result of the improved testing method from manual to fully automated and sensitivity of screening test(table 1) and with the constant increase of first time blood donors mainly family blood donors.

According to donors status, the prevalence of HBsAg was lower in voluntary non remunerate blood donors than commercial donors and family replacement blood donors. In family replacement blood donors, the prevalence was higher than voluntary blood donors but lower than paid donors (figures 2). So, it is important to encourage the voluntary blood donors to become regularly blood donors. Screening the blood donors for anti$\mathrm{HBC}$ or HBV DNA has reduced the risk of transmition of HVB infection by transfusion of blood and his products [27]. It is generally accepted that the diagnosis of infection by $\mathrm{HBV}$ is based on the presence of the HBsAg in the bloodstream [28]. However, screening of blood donors for HBsAg does not totally eliminate the risk of $\mathrm{HBV}$ infection through blood transfusion [29] since the absence of this marker in the serum does not exclude the presence of HBV DNA [30-33]. It is possible that, donors with occult $\mathrm{HBV}$ infection, who lacked detectable $\mathrm{HBsAg}$ but whose exposure to HBV infection was indicated by a positive anti-HBc and HBV DNA, are a potential source of HBV infection [34-36].

Our pilot study revealed that 133 of 225 (59.1\%) $\mathrm{HBsAg}$ negative blood donors were anti-HBc positive and thus were exposed to HBV infection. The isolated finding of anti- $\mathrm{HBc}$ antibody in $\mathrm{HBsAg-negative} \mathrm{subjects}$ was considered a marker of past exposure to HBV and of resolved infection. Results obtain from deferent studies in blood donors has shown that HBV DNA was detected in $1.6 \%$ to $38 \%$ of $\mathrm{HBsAg}$ negative/anti $\mathrm{HBc}$ positive blood donors $[34,27,37]$. Thus these donors my be the potential to transmit HBV through transfusion.

The absence of HBsAg in the blood of apparently healthy individuals may not be sufficient to ensure lack of circulating HBV. Blood containing anti-HBc with or without detectable presence of HBsAg might be infectious, therefore routine blood donor screening for anti$\mathrm{HBc}$ has been implemented in some countries resulting in a decrease in the risk of post-transfusion HBV infection [38].

While anti-HBc-positive blood donor may be a potential source of HBV transmission, routine application of anti-HBc screening is not feasible in Albania. Our findings in random screening $\mathrm{HBsAg}$ negative blood donors

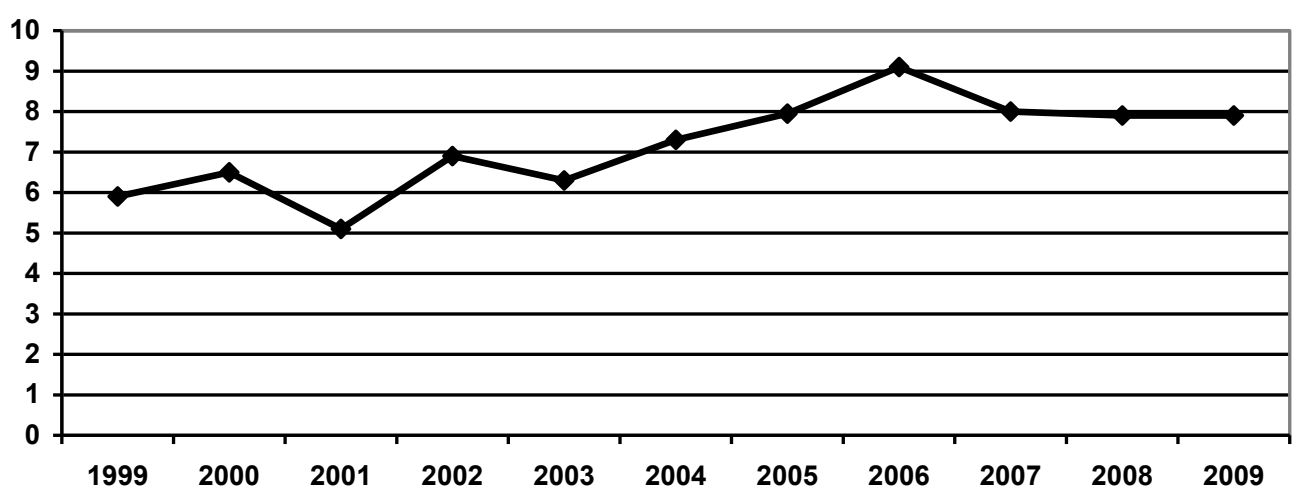

Figure $1 \mathrm{HBsAg}$ prevalence in blood donors during 1999-2009 years 


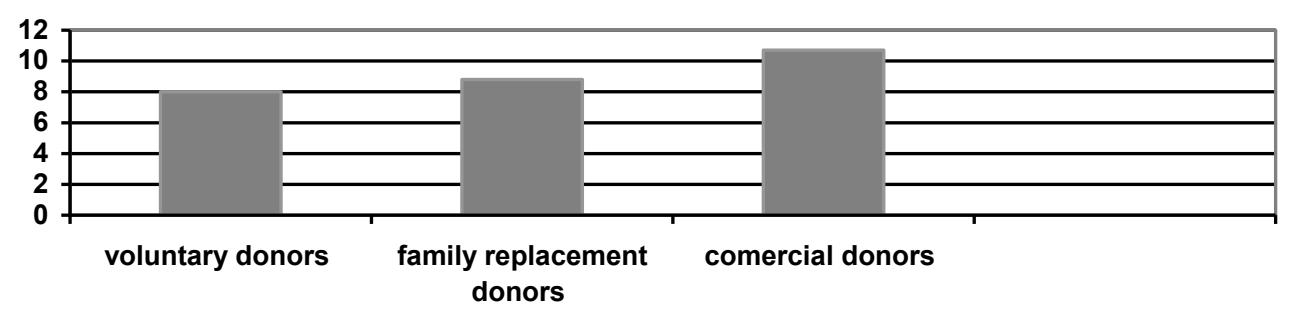

Figure $2 \mathrm{HBsAg}$ prevalence based on blood donor status.

for anti-HBc are the same with anti-HBc prevalence rates among HBsAg-negative blood donors in endemic area when the prevalence of anti-HBc is over 57\% [39].

In country with intermittent and low prevalence of $\mathrm{HBsAg}$, anti-HBc prevalence vary from, $0.56 \%$ in the United Kingdom, $0.84 \%$ in United States, $1.4 \%$ in Germany, $15.03 \%$ in Greece [10,34-38]. In our study the HBsAg negative/anti-HBc positive donor population is carry out in two blood donors groups, regular blood donors and first time blood donors. The prevalence rate of anti-HBc was higher in first time blood donors than regularly donors. So, the establishment of a panel of regular blood donors is very important in providing safe blood and blood products. Anti-HBc screening of blood donations is controversial and variably performed in different countries. Currently it is limited to areas where the seroprevalence of HBV is low (generally $<2 \%$ ), while it is not performed in areas with a high HBV seroprevalence because the impact of the deferral of anti-HBc-positive donors is considered not sustainable. However, the prevalence of occult HBV infection is higher in areas in which HBV infection itself is more frequent. The safety of this measure is currently being debated [40-42]. Our study underscores the increasing the HBsAg prevalence in our donor population. This trend, suggest that routine antiHBc screening of blood donors could possibly prevent some transfusion-transmitted HBV infections from blood donors. However, usefulness of screening for anti-HBc in addition to HBsAg detection and introduction of PCR based screenings like NAT to improve the safety of the blood supply in Albania deserves further analysis.

\section{Author details \\ 'Hospital Planning Directory, Ministry of Health, Bulevardi "Bajram Curri", No.1, Tirana, Albania. ${ }^{2}$ Department of Chronic Diseases Epidemiology and policies, Public Health Institute Rruga" Aleksander Moisiu", No 30, Tirana, Albania.}

\section{Authors' contributions}

VD carried data collecting, participated in design of the study and drafted manuscript. SHQ participated in design of the study and performed the statistical analysis. Both authors read and approved the final manuscript.

\section{Competing interests}

The authors declare that they have no competing interests.
Received: 21 December 2010 Accepted: 4 March 2011

Published: 4 March 2011

\section{References}

1. Glynn SA, Kleinman SH, Schreiber GB, Busch MP, Wright DJ, Smith JW, Nass CC, Williams AE: Trends in incidence and prevalence of major transfusion transmissible viral infection in the United States blood donors, 1991 to 1996. JAMA 2000, 284:229-235.

2. Schreiber GB, Busch PM, Kleinman SH, Korelitz JJ: The risk of transfusion transmitted viral infection. N Engl J Med 1996, 334:1685-1690.

3. Michael PBusch, HIV, HBV and HCV: New development related to transfusion safety. Vox Sang 2000, 78:253-256.

4. Selim Badur: Transfusion transmitted virus. Plenary et state of the art book. ISBT 2003, 119-121.

5. Soldan K, Davison K, Dow B: Estimates of the frequency of HBV, HCV and HIV infectious donations entering the blood supply in the United Kingdom, 1996 to 2003. Eurosurveillance 2005, 10:9-10.

6. Dodd RY, Notari EP, Stramer SL: Current prevalence and incidence of infectious disease markers and estimated window-period risk in the American Red Cross blood donor population. Transfusion 2002, 42:975-979.

7. Comanor L, Holland P: Hepatitis B virus blood screening: unfinished agendas. Vox Sanguinis 2006, 91:1-12

8. Pillonel J, Laperche S, I'Eta-blissement Francais du Sang: Trends in risk of transfusion transmitted viral infections (HIV, HCV, HBV) in France between 1992 and 2003 and impact of nucleic acid testing (NAT). Eurosurveillance 2005, 10:5-6.

9. Stroffolini T, Mele A, Tosti ME, Gallo G, Balocchino E, Ragni P, Santonastasi F, Marzolini A, Ciccozzi M, Moiraghi A: The impact of the hepatitis B mass immu-nisation campaign on the incidence and risk factors of acute hepatitis B in Italy. J Hepatol 2000, 33:980-5.

10. Manzini Paola, Girotto Mauro, Borsotti Raffaele, Giachino Osvaldo, Guaschino Roberto, Lanteri Maurizio, Testa Domenico, Ghiazza Paola, Vacchini Maria, Danielle Franca, Pizzi Alessandra, Valpreda Chiara, Castagno Franco, Curti Franco, Magistroni Paola, Maria Lorena Abate, Smedile Antonina, Mario Rizzetto: Italian blood donors with anti-HBC and occult hepatitis B virus infection. Haematologica 2007, 92(12):1664-1670.

11. Raimondo G, Pollicino T, Cacciola I, Squadrito G: Occult hepatitis B virus infection. J Hepatol 2007, 46:160-70.

12. Matsumoto C, Tadokoro K, Fujimura K, Hirakawa S, Mitsunaga S, Juji T: Analysis of HBV infection after blood transfusion in Japan through investigation of a comprehensive donor specimen repository. Transfusion 2001, 41:878-84.

13. Nelaj Erida, Bino Silva, Kadare llirjana, Eduard Kakarriqi: Evaluate of immunization program with hepatitis B vaccine. Institute of Public Health Bulletin; 2007:2:3-23.

14. World Health Organization: Weekly epidemiological record No.40. 2009, 84:405-420.

15. Mahoney Fj, Kane M: Hepatitis B vaccine. In Vaccines. 3 edition. Edited by: Plotkin SA, Orenstein WA. Philadelphia, WB. Saunders Company; 1999:158-182.

16. WHO: Viral hepatitis prevention board. Universal HB immunization by 1997: where are now? 1998 [http://hgins.uia.ac.be/esoc/NHPB/vhfs2.htlm], Fact sheet VHPB/1998/2,

17. World Health Organization: Introduction of Hepatitis B Vaccine into Childhood Immunization Services. WHO, Geneva; 2001. 
18. Alter MJ, Kruszon-Moran D, Nainan OV, Mc Quillan GM, Gao F, Moyer LA, Kaslow RA, Margolis HS: The prevalence of hepatitis $C$ virus infection in the United States, 1988 through 1994. The New England Journal of Medicine 1999, 341(8):556-562, 1999.

19. Soldan K, Barbara JAJ, Dow BC: Transfusion transmitted hepatitis B virus infection in the UK: a small and moving target. Vox Sanguinis 2002, 83:305-308, of Medicine, 341, 556-562.

20. Gurol Emekdas, Saban Cavuslu, Oral Oncul, Cigdem Artuk, Aksoy Armagan: Trends of hepatitis B and C virus among blood donors over 16 years in Turkey. Europian Journal of Epidemiology 2006, 21:299-305.

21. Foudoulaki L, Kyriakis KP, Fakitsa V, Giagiozis A, Kourenti K, Sofroniadou K: Long term surveillance of viral diseases marker in large blood transfusion centre in Greece. ISBT 2004. Vox Sanguinis 2004, 87(suppl 3): S93-S125.

22. Fejza Hajrullah, Skender Telaku: Prevalence of HBV and HCV among blood donors in Kosovo. Virology Journal 2009, 6:21.

23. Blood services in south-eastern Europe: Current status and challenges. WHO regional office for Europe; 2007, 71-121.

24. Ortakovska S, Balamovski M, Timova T: Viral markers in voluntary blood donors in Macedonia. ISBT 2004, Vox Sanguinis 2004, 87(suppl 3):S93-s125.

25. Giusti G, Gaeta GB, Russo M, Bedarida G: HBsAg carries among blood donors in Italy-A multicenter study in 107 blood bank. Infection 1989, 17(4):237-43.

26. Basho Mimoza: The seroprevalence of viral hepatitis in Albanian people. International Conference of Hyppocraty in Tirana. 20-22 November 2003. Abstract book 2003, 54

27. Jongerius JM, Wester M, Cuypers HT, Van Oostendorp WR, Lelie PN, Van Der Poel CL, Van Leeuwen EF: New hepatitis B virus mutant form in a blood donor that is undetectable in several hepatitis B surface Antigen screening assays. Transfusion 1998, 38:56-9.

28. Henning H, Puchta I, Luhm J, et al: Frequency and load of hepatitis B virus DNA in first-time blood donors with antibodies to hepatitis B core antigen. Blood 2002, 100(7):2637-41.

29. Badur S, Akgun A: Diagnosis of hepatitis B infections and monitoring of treatment. J Clin Virol 2001, 21:229-237.

30. Allain JP: Occult hepatitis B virus infection. Transfus Clin Biol 2004, 11:18-25.

31. Mahoney JFrancis: Update on Diagnosis, Management, and Prevention of Hepatitis B Virus Infection Clinical Microbiology Review. 1999, 12(2):351-366.

32. Brechot $C$, Thiers $V$, Kremsdorf $D$, Nalpas B, Pol S, Paterlini-Brechot $P$ : Persistent hepatitis $B$ virus infection in subjects without hepatitis $B$ surface antigen: clinically significant orpurely "occult"? Hepatology 2001, 34:194-203.

33. Wang JT, Lee $C Z$, Chen PJ, Wang TH, Chen DS: Transfusion transmitted $\mathrm{HBV}$ infection in an endemic area: the necessity of more sensitive screening for HBV carriers. Transfusion 2002, 42:1592-7.

34. Yotsuyanagi H, Yasuda K, Moriya K, Shintani Y, Fujie H, Tsutsumi T, Nojiri N, Juji T, Hoshino H, Shimoda K, Hino K, Kimura S, lino S, Koike K: Frequent presence of $\mathrm{HBV}$ in the sera of HBsAg-negative, anti-HBc-positive blood donors. Transfusion 2001, 41:1093-1099.

35. Allain JP, Hewitt PE, Tedder RS, Williamson LM: Evidence that anti-HBc but not HBV DNA testing may prevent some HBV transmission by transfusion. British Journal of Haematology 1999, 107:186-195.

36. Zervou EK, Dalekos GN, Boumba DS, Tsianos EV: Value of anti-HBC screening of blood donors for prevention of HBV infection: results of a 3-year prospective study in Northwestern Greece. Transfusion 2001, 41:652.

37. Dreier J, Kroger M, Diekmann C, Gotting C, Kleesiek K: Low-level viremia of hepatitis B virus in an anti-HBC- and anti-HBs-positive blood donor. Transfusion Medicine 2004, 14:97-103.

38. Kleinman SH, Kuhns MC, Todd DS, Glynn SA, McNamara A, DiMarco A, Busch MP: Frequency of HBV DNA detection in US blood donors testing positive for the presence of anti-HBc: Implications for transfusion transmission and donor screening. Transfusion 2003, 43:696-704

39. Nilton R, Donaida M, Aricio T: Seroprevalence of HBsAg, anti-HBc and anti-HCV in Sourthen Brazil 1999-2001. Brazil Journal of Infection Diseases 2003, 7(4):262-7.

40. Rosini N, Mousse D, Spada C, Treitinger A: Seroprevalence of HBsAg, antiHBC and anti-HCV in southern Brazil, 1999-2001. Brazilian Journal of Infectious Diseases 2003, 7:262-267.
41. Turchi Martelli Celina maria, Turchi Marilia Dalva, Francisco Jose dutra Souto, Amadeo Saez-Alqezar, Andrade SSAna Lucia, Fabio Zicker: Anti-Hbc testing for blood donations in area with intermediate hepatitis B endemicity. Rev Panam Salud Publica/Pan Am J Public Health 1999, 6(1):69-73.

42. Busch MP: Prevention of transmission of hepatitis $B$, hepatitis $C$ and Human Immunodeficiency Virus infections through blood transfusion by anti-HBc testing. Vox Sang 1998, 74(Suppl 2):147-154.

doi:10.1186/1743-422X-8-96

Cite this article as: Durro and Qyra: Trends in prevalence of hepatitis B virus infection among Albanian blood donors, 1999-2009. Virology Journal 2011 8:96.

\section{Submit your next manuscript to BioMed Central and take full advantage of:}

- Convenient online submission

- Thorough peer review

- No space constraints or color figure charges

- Immediate publication on acceptance

- Inclusion in PubMed, CAS, Scopus and Google Scholar

- Research which is freely available for redistribution

Submit your manuscript at www.biomedcentral.com/submit
C Biomed Central 